\title{
PACIFIC NORTHWEST LABORATORY MONTHLY REPORT ON SPACE NUCLEAR SYSTEMS PROGRAM FOR PERIOD ENDING JULY 1974
}

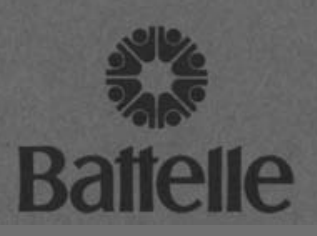

Pacific Northwest Laboratories Richland, Washington 99352

Prepared for the U.S. Atomic Energy Commission under Contract AT(45-1): 1830 


\title{
NOTICE
}

This report was prepared as an account of work sponsored by the United States Government. Neither the United States nor the United States Atomic Energy Commission, nor any of their employees, nor any of their contractors, subcontractors, or thier employees, makes any warranty, express or implied, or assumes any legal liability or responsibility for the accuracy, completeness or usefulness of any information, apparatus, product or process-disclosed, or represents that its use would not infringe privately owned rights.

\section{PACIFIC NORTHWEST LABORATORY operated by \\ BATTEШE \\ for the}

U.S. ATOMIC ENERGY COMMISSION Under Contract AT(45-1)-1830

\author{
Printed in the United States of America \\ Available from \\ National Technical Information Service \\ U.S. Department of Commerce \\ 5285 Port Royal Road \\ Springfield, Virginia 22151 \\ Price: Printed Copy \$5.45; Microfische \$2.25
}




\author{
PACIFIC NORTHWEST LABORATORY \\ MONTHLY REPORT \\ ON SPACE NUCLEAR SYSTEMS PROGRAM \\ FOR JULY 1974 \\ by \\ H. T. Fullam
}

August 1974

BATTELLE

PACIFIC NORTHWEST LABORATORIES

RICHLAND, WASHINGTON 99352 


\section{TABLE OF CONTENTS}

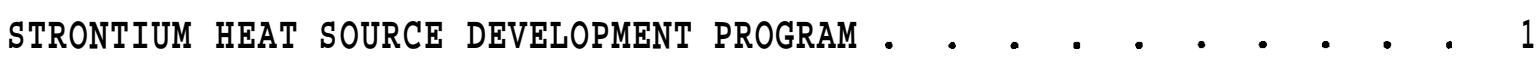

Strontium Fluoride Compatibility Tests . . . . . . . . . . 1

$\mathrm{SrF}_{2}$ Dissolution Rates in Aqueous Media . . . . . . . . . 4

$\mathrm{SrF}_{2}$ Physical Property Measurements . . . . . . . . . . . 7

WESF ${ }^{90} \mathrm{SrF}_{2}$ Capsule Analysis . • . • • • • • • • • • • • 7

Thermodynamic Analysis of ${ }^{90} \mathrm{SrF}_{2}$ Compatibility . . . . . . . 8

$\mathrm{SrF}_{2}$ Compatibility Program Plan . . . . . . . . . . . 8 


\section{PACIFIC NORTHMEST LABORATORY \\ MONTHLY REPORT \\ ON SPACE NUCLEAR SYSTEMS PROGRAM}

FOR JULY 1974

\section{STRONTIUM HEAT SOURCE DEVELOPMENT PROGRAM}

A t Hanford, strontium wizl be separated from the high-Zevel waste, then converted to the fluoride, and doubly encapsulated in small, high-integrity containers for subsequent long-term storage. The fluoride conversion, encapsulation and storage will take place in the Waste Encapsulation and Storage Facilities (WESE). This encapsulated strontium fluoride represents an economical source of ${ }^{90} \mathrm{Sr}$ if the WESF capsule can be licensed for heat source applications under anticipated use conditions. The objectives of this program are to obtain the data needed to Zicense ${ }^{90}{ }_{S r F} 2$ heat sources and specifically the WESF ${ }^{90}{ }_{S r F} 2$ capsules. The information needed for licensing can be divided into three general areas:

1. Long-term SrF2 compatibility data.

2. Chemical and physical property data on $90 \mathrm{SrF}_{2}$.

3. Capsule property data such as external corrosion resistance, crush strength, etc.

The current program is designed to provide the required information.

\section{STRONTIUM FLUORIDE COMPATIBILITY TESTS}

The short-term compatibility tests with high-purity, nonradioactive $\mathrm{SrF}_{2}$, containing controlled levels of added impurities, are continuing as scheduled. The 1500 -hour tests, conducted at $1000^{\circ} \mathrm{C}$, have been completed and the couples are being evaluated; the 4400 -hour $1000^{\circ} \mathrm{C}$ tests will be completed in October. Metallographic examination of a number of the 1500-hour couples has been completed and photomicrographs have been obtained. Preliminary estimates of the amount and types of metal attack observed, based on the photomicrographs, are presented in Table 1. A more detailed analysis of metal-fluoride interaction and correlation of impurity effects will be reported when all of the photomicrographs and electron microprobe (EMP) data are available. 


\section{TABLE 1. Preliminary Compatibility Data for Couples Containing High-Purity, Nonradioactive SrF2 with Controlled Levels of Specific Impurities Added - After $1500 \mathrm{hr}$ at $1000 \circ \mathrm{C}$}

\begin{tabular}{|c|c|c|c|}
\hline Metal & $\begin{array}{l}\text { Impurity } \\
\text { Added }\end{array}$ & $\begin{array}{l}\text { Depth of Metal** } \\
\text { Affected, Mils }\end{array}$ & Remarks (types of attack observed)** \\
\hline TZM* & $\mathrm{Va}$ & $\ll 1$ & Slight surface roughening-slight pitting. \\
\hline TZM & $\mathrm{Pb}$ & $<1$ & Pitting, intergranular attack. \\
\hline TZW & $\mathrm{Cu}$ & $1-2$ & Intergranular attack-subsurface void formation. \\
\hline TZW & $\mathrm{Fe}$ & $1-2$ & Heavy Pitting. \\
\hline TZM* & Al & $\ll 1$ & Slight surface roughening. \\
\hline $\mathrm{T} \triangle \mathrm{M}^{*}$ & 3 & $\ll 1$ & Slight surface roughening. \\
\hline TZM & ${ }^{7} 2^{0}$ & $<1$ & Surface roughening - slight pitting. \\
\hline W & $\mathrm{Na}$ & $\ll<1$ & Slight surface roughening, metal sample badly fractured.'a) \\
\hline$W^{*}$ & in & $<1$ & Slight lay red surface attack. \\
\hline$W^{*}$ & $\mathrm{~Pb}$ & 0 & No visib'e attack, metal sample fractured. \\
\hline W & $\mathrm{Cu}$ & $1-2$ & Pitting, sume surface attack. \\
\hline$W^{\star}$ & $\mathrm{NO}_{3}$ & 0 & No visible attack, sample fractured. \\
\hline$W^{*}$ & $t_{2}{ }^{\gamma}$ & $<1$ & Slight pitting, samples fractured. \\
\hline Hastelloy $\mathrm{N}^{*}$ & $\mathrm{Na}$ & 3-4 & Layered surface attack, heavy subsurface void formation. \\
\hline Hastelloy $\mathrm{N}$ & $\mathrm{Mn}$ & & Layered surface attack, subsurface void formation. \\
\hline Hastelloy $\mathrm{N}$ & $\mathrm{Pb}$ & $2-3$ & Pitting, subsurface void formation. \\
\hline Has te lloy $\mathrm{N}^{*}$ & $\mathrm{Cu}$ & $4-5$ & General surface attack, pitting, heavy subsurface void formation. \\
\hline Hastelloy $\mathrm{N}^{*}$ & $\mathrm{Fe}$ & $10-12$ & Extremely heavy subsurface void formation. \\
\hline
\end{tabular}

Indicates couples which were overheated to $1200^{\circ} \mathrm{C}$ for a few hours.

** Estimated from photomicrographs - more detailed ata will be presented when electron microprobe results are avai lable.

ia) Fracture of the tungsten specimens appeared to h .ve occurred during couple fabrication rather than as the result of $\mathrm{SrF}_{2}$ attack. 
TABLE 1. (contd)

\begin{tabular}{|c|c|c|c|}
\hline Metal & $\begin{array}{l}\text { Impurity } \\
\text { Added }\end{array}$ & $\begin{array}{l}\text { Depth of Metal }\left.\right|^{* *} \\
\text { Affected, Mils }\end{array}$ & Remarks (types of attack observed) ${ }^{* *}$ \\
\hline $\begin{array}{l}\text { Hastelloy } \mathrm{N}^{*} \\
\text { Hastelloy } \\
\text { Hastelloy } \\
\text { Hastelloy } \\
\text { Hastelloy } \mathrm{N}^{*}\end{array}$ & $\begin{array}{l}\mathrm{Al} \\
\mathrm{Ca}-\mathrm{Ba}-\mathrm{Mg} \\
\mathrm{O}^{-2}- \\
\mathrm{NO}_{3}^{-} \\
\mathrm{H}_{2} \mathrm{O}\end{array}$ & $\begin{array}{r}2-3 \\
2-3 \\
20-25 \\
---2\end{array}$ & $\begin{array}{l}\text { Slight subsurface void fonnation. } \\
\text { Slight pitting, slight subsurface void formation. } \\
\text { Extremely heavy intergranular attack and leaching of surface. } \\
\text { Results not yet available. } \\
\text { Subsurface void formation. }\end{array}$ \\
\hline $\begin{array}{l}\text { Hast } C-276^{\star} \\
\text { Hast } \mathrm{C}-276 \\
\text { Hast } \mathrm{C}-276^{\star} \\
\text { Hast } \mathrm{C}-276 \\
\text { Hast } \mathrm{C}-276 \\
\text { Hast } \mathrm{C}-276^{\star} \\
\text { Hast C-276 } \\
\text { Hast } \mathrm{C}-276 \\
\text { Hast } \mathrm{C}-276^{\star} \\
\text { Hast } \mathrm{C}-276^{\star}\end{array}$ & $\begin{array}{l}\mathrm{Na} \\
\text { in } \\
\mathrm{Pb} \\
\mathrm{O} \\
\mathrm{Fe} \\
\mathrm{Al} \\
\mathrm{Ca}-\mathrm{Ba}-\mathrm{Mg} \\
\mathrm{O}^{-2} \\
\mathrm{NO}_{3}^{-} \\
\mathrm{H}_{2} \mathrm{O}\end{array}$ & $\begin{array}{r}2-3 \\
2-3 \\
1-2 \\
6-8 \\
---2 \\
1-2 \\
2-3 \\
10-12 \\
3-4 \\
4-6\end{array}$ & $\begin{array}{l}\text { Some pitting, some subsurface void formation. } \\
\text { Some intergranular attack and pitting. } \\
\text { Subsurface void formation and pitting. } \\
\text { General surface attack, some deep subsurface void formation. } \\
\text { Results not yet available. } \\
\text { Subsurface void formation. } \\
\text { General surface attack, some pitting and sub-surface voids. } \\
\text { Heavy intergranular attack and subsurface void formation. } \\
\text { General surface attack, some pitting and subsurfave voids. } \\
\text { Pitting, intergranular attack, some subsurface voids. }\end{array}$ \\
\hline $\begin{array}{ll}\text { Inconel } & 600^{*} \\
\text { Inconel } & 600 \\
\text { Inconel } & 600 \\
\text { Inconel } & 600^{\star} \\
\text { Incone] } & 600^{*} \\
\text { Inconel } & 600 \\
\text { Inconel } & 600 \\
\text { Inconel } & 600 \\
\text { Inconel } & 600^{*} \\
\text { Inconel } & 600^{\star}\end{array}$ & $\begin{array}{l}\mathrm{Na} \\
\mathrm{Hb} \\
\mathrm{Pb} \\
\mathrm{Ou} \\
\mathrm{Fe} \\
\mathrm{Al} \\
\mathrm{Ca}-\mathrm{Ba}-\mathrm{Mg} \\
\mathrm{O}^{-2} \\
\mathrm{NO}_{3}^{-} \\
\mathrm{H}_{2} \mathrm{O}\end{array}$ & $\begin{array}{r}1 \\
2-5 \\
2-3 \\
2-3 \\
4-6 \\
<1 \\
2-3 \\
15-20 \\
2-3 \\
1\end{array}$ & $\begin{array}{l}\text { General surfrce attack, some pitting. } \\
\text { Some pitting ubsurface void formation. } .^{* *} \\
\text { General surf,ce attack, subsurface void formation. }{ }^{* \star \star} \\
\text { Pitting, subsurface void formation. } \\
\text { Heavy subsurface void formation.*** } \\
\text { Slight pitting and surface roughening. } \\
\text { Slight layered surface attack, some subsurface void formation. } \\
\text { Heavy interaranular attack and surface leaching. } \\
\text { General surface attack, subsurface void formation. }{ }^{* * *} \\
\text { Slight surface roughening, subsurface void formation. }{ }^{* * *}\end{array}$ \\
\hline $\begin{array}{l}\text { Haynes } 188 \\
\text { Haynes } 188^{\star} \\
\text { Haynes } 188 \\
\text { Haynes } 188^{\star} \\
\text { Haynes } 188\end{array}$ & $\begin{array}{l}\mathrm{Na} \\
\mathrm{Mn} \\
\mathrm{Pb} \\
\mathrm{Cu} \\
\mathrm{Fe}\end{array}$ & $\begin{array}{r}<1 \\
? \\
4-67 \\
10-12 ? \\
10-12 ?\end{array}$ & $\begin{array}{l}\text { Slight surface roughening. } \\
\text { Need electron micmprobe (EMP) data to evaluate attack. } \\
\text { Some pitting, subsurface voids (need BMP data to evaluate attack). } \\
\text { Subsurface void formation? (need EMP data to evaluate attack). } \\
\text { Subsurface void formation? (need BNP data to evaluate attack). }\end{array}$ \\
\hline $\begin{array}{l}\text { Haynes } 188 \\
\text { Haynes } 188 \\
\text { Haynes } 188 \\
\text { Haynes } 188^{\star} \\
\text { Haynes } 188^{\star}\end{array}$ & $\begin{array}{l}\mathrm{A} 1 \\
\mathrm{Ca}-\mathrm{B} \mathrm{a}_{-2} \mathrm{Mg} \\
\mathrm{O}^{-2} \\
\mathrm{NO}_{3}^{-} \\
\mathrm{H}_{2} \mathrm{O}\end{array}$ & $\begin{array}{r}<1 \\
10-12 \\
3-41 \\
3-41\end{array}$ & $\begin{array}{l}\text { Slight surface roughening. } \\
\text { Slight surface roughening. } \\
\text { Heavy intergrinular attack. } \\
\text { Slight surfice attack need EMP data to evaluate subsurvace voids } \\
\text { Slight surfice attack [need EMP data to evaluate subsurface voids). }\end{array}$ \\
\hline
\end{tabular}


In the 1500-hour tests, a furnace controller failure occurred the day the tests were to be stopped. As a result, one furance (of six) overheated to about $1200^{\circ} \mathrm{C}$ when failure occurred and the couples in the furnace were above $1000^{\circ} \mathrm{C}$ for about 4 hours which could affect the results. Of a total 108-1500-hour couples, 42 were overheated. These affected couples are indicated by the footnotes in Table 1. Results of the 4400-hour tests will be needed to determine the overall effect of the overheating.

The overheating occurred due to failure of two separate systems in the temperature controller. The controller SRC failed, allowing continuous power input while, at the same time, an over-temperature control switch failed. To prevent a similar occurrence with the other furnaces, another over-temperature switch will be installed in each furnace system. These switches will operate off the thermocouples used to monitor each furnace temperature and will be set up to shut off power to the furnace if the temperature exceeds a predetermined level.

A total of 108 couples, containing high-purity ${ }^{90} \mathrm{SrF}_{2}$ or WESF grade ${ }^{90} \mathrm{SrF}_{2}$ (prepared by $\mathrm{PNL}$ ), have been tested as part of the short-term compatibility test program and evaluation of these couples is now underway. To date, seven couples have been examined, 12 are at Postirradiation Testing (operated by HEDL) for metallographic examination, 20 are at PNL ready for examination, and 15 have been sectioned. The other couples are in the process of being sectioned.

ईrF DISSOLUTION RATES IN AQUEOUS MEDIA

The dissolution rates of several grades of nonradioactive $\mathrm{SrF}_{2}$ in demineralized water were obtained using a dynamic (flow) test system. A sketch of the experimental setup is shown in Figure 1. In the tests, demineralized water was flowed at a constant rate into the reaction chamber containing the $\mathrm{SrF}_{2}$. The overflow from the reaction vessel was sampled periodically, filtered through an 0.05-um Millipore filter, and analyzed for its strontium and fluoride content. In general, the strontium dissolution rate was high initially, then decreased with time until an equilibrium level was reached. The time required to reach equilibrium 


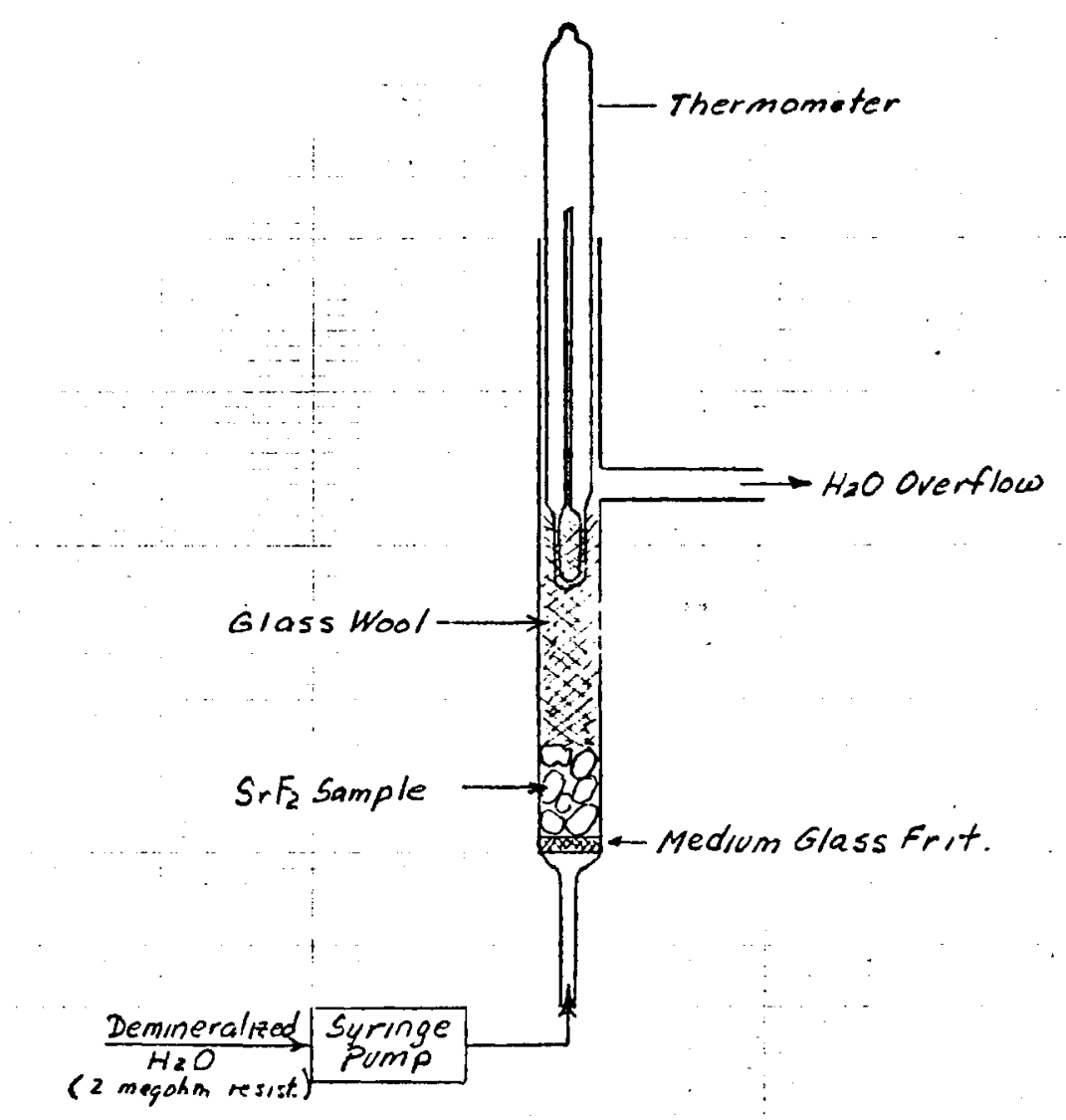

FIGURE 1. Dynamic (Flow) System for $\mathrm{SrF}_{2}$ Dissolution Rate Measurements

varied somewhat between samples, but normally the equilibrium level was attained within 24 hours. Results obtained with the various $\mathrm{SrF}_{2}$ samples are summarized in Table 2. In two of the tests the water flow rate was varied periodically to determine the effect on the dissolution rate, but in each case it was found the dissolution rate was unaffected (within experimental error) by changes in water flow.

With $\mathrm{SrF}_{2}$, the water leaving the reaction vessel should contain two moles of fluoride per mole of strontium, which was the case when the system was at equilibrium. However, during the early stages of each run, when the dissolution rate was changing, the $\mathrm{F}^{-} / \mathrm{Sr}^{+2}$ was not 2. If the $\mathrm{SrF}_{2}$ contained a substantial amount of $\mathrm{NaF}$ (see Run 4 in Table 2) the 
TABLE 2. Dissolution Rates of Nonradioactive $\mathrm{SrF}_{2}$ in Demineralized Water at $25^{\circ} \mathrm{C}$ - Obtained with a Dynamic (Flow) System

\begin{tabular}{|c|c|c|}
\hline Run No, & Grade of $\mathrm{SrF}_{2}$ & $\begin{array}{c}\text { Equil. Dissolution Rate } \\
\left(\mu \mathrm{g} \mathrm{S} / \mathrm{hr}-\mathrm{g} \mathrm{SrF}_{2}\right)\end{array}$ \\
\hline 1 & $\begin{array}{l}\text { High purity } \mathrm{SrF}_{2} \text { containing } 0.5 \% \text { im- } \\
\text { purities (including } 0.4 \% \mathrm{Na} \text { ) which was } \\
\text { fired at } 1100^{\circ} \mathrm{C} \text { for } 20 \text { hours, cooled } \\
\text { to room temperature and crushed to }-1 / 4 " \\
+1 / 8^{\prime \prime} \text { lumps. }\end{array}$ & 435 \\
\hline 2 & $\begin{array}{l}\text { Same as } \# 1 \text { except material was fired at } \\
900^{\circ} \mathrm{C} \text { for } 20 \text { hours. }\end{array}$ & 640 \\
\hline 3 & $\begin{array}{l}\text { Commercial } \mathrm{SrF}_{2}(0.5 \% \text { impurities }) \text { fired } \\
\text { at } 1100^{\circ} \mathrm{C} \text { for } 84 \text { hours, cooled to room } \\
\text { temperature and crushed to }-1 / 4^{\prime \prime}+1 / 8^{\prime \prime} \\
\text { lumps. }\end{array}$ & 160 \\
\hline 4 & $\begin{array}{l}\text { High purity } \mathrm{SrF}_{2}(99.9 \%) \text { mixed with } 10 \% \\
\mathrm{NaF} \text { and fired at } 1100^{\circ} \mathrm{C} \text { for } 20 \text { hours, } \\
\text { cooled and crushed to }-1 / 4^{\prime \prime}+1 / 8^{\prime \prime} \text { lumps. }\end{array}$ & 640 \\
\hline 5 & $\begin{array}{l}\text { High purity } \mathrm{SrF}_{2}(99.9 \%) \text { fused at } 1500^{\circ} \mathrm{C} \text {, } \\
\text { cooled to room temperature and crushed to } \\
-1 / 4^{\prime \prime}+1 / 8^{\prime \prime} \text { lumps. }\end{array}$ & 120 \\
\hline 6 & $\begin{array}{l}\text { High purity } \mathrm{SrF}_{2}(99.9 \%) \text { cold pressed in- } \\
\text { to pell et }(70 \% \text { of } \mathrm{TD}) \text {, fired four hours } \\
\text { at } 1100^{\circ} \mathrm{C} \text {, cooled and broken into }-1 / 4^{\prime \prime} \\
+1 / 8^{\prime \prime} \text { lumps. }\end{array}$ & 246 \\
\hline 7 & $\begin{array}{l}\text { High purity } \mathrm{SrF}_{2}(99.9 \%) \text { fired at } 1100^{\circ} \mathrm{C} \\
\text { for } 20 \text { hours, cooled and crushed to }-1 / 4^{\prime \prime} \\
+1 / 8^{\prime \prime} \text { lumps. }\end{array}$ & Samples being analyzed \\
\hline
\end{tabular}


$\mathrm{F}^{-} / \mathrm{Sr}^{+2}$ ratio of the solution was much greater than 2 during the initial phase of the run because of the rapid dissolution of the NaF. In addition, the initial dissolution rate of the $\mathrm{SrF}_{2}$ was lower than usual. When the $\mathrm{SrF}_{2}$ contained very little $\mathrm{NaF}$ (Runs 5 and 6 in Table 2), the $\mathrm{F}^{-} / \mathrm{Sr}^{+2}$ ratio in the solution was less than 2 during the initial portion of the run and the initial dissolution rate was quite high. Preliminary indications are that this is due to the presence of $\mathrm{SrO}$ in the $\mathrm{SrF}_{2}$ and the SrO dissolves quite rapidly.

\section{SrF PHYSICAL PROPERTY MEASUREMENTS}

Efforts are underway to determine the thermal conductivity of $\mathrm{SrF}_{2}$ by measuring the thermal diffusivity and heat capacity of $\mathrm{SrF}_{2}$, and calculating the thermal conductivity. (The experimental measurements will be made by J. L. Bates of the Ceramics and Graphite Section.) Three grades of $\mathrm{SrF}_{2}$ will be studied: high purity $\mathrm{SrF}_{2}(<0.1 \%$ impurities), commercial $\mathrm{SrF}_{2}\left(0.5 \%\right.$ impurities), and WESF grade $\mathrm{SrF}_{2}$ ( $\sim 4 \%$ impurities). We are currently in the process of preparing small cold-pressedpellets of various densities from the three grades of $\mathrm{SrF}_{2}$ to be used in the tests. While $\mathrm{SrF}_{2}$ is easily compacted to fairly high densities by cold pressing, it is difficult to obtain stable pellets in the dimensions needed $(0.375$-in. diameter $\times 0.05$-in. thick) for the tests. Satisfactory pellets can be obtained using a die lubricant, but removal of the lubricant from the pellet is difficult. Ways to remove the lubricant are now being investigated.

\section{WESF ${ }^{90} \mathrm{SrF}_{2}$ CAPSULE ANALYSIS}

A preliminary analysis of the WESF capsule design indicates it will probably fail to meet one or more of the IAEA Series 33 tests. This holds true whether the capsule material is Hastelloy C-276, Hastelloy $X$, Incone1 600 or Haynes 25. W. E. Anderson (Structures and Mechanics Section) studied the problem in detail and concluded that a more thorough study 
involving fracture mechanics and experimental testing is required to adequately predict capsule integrity under IAEA Series 33 test conditions. The possibility of including such a study in the current program is being investigated.

THERMODYNAMIC ANALYSIS OF ${ }^{90} \mathrm{SrF}_{2}$ COMPATIBILITY

The computer program to be used in the thermodynamic analysis of ${ }^{90} \mathrm{SrF}_{2}$ compability is ready for use. The study will be made by R. P. Turcotte (and others) in the Ceramics and Graphite Section. Work on the program is underway at a limited rate for the present time, but the major effort will start in September.

\section{SrFF COMPATIBILITY PROGRAM PLAN}

Efforts are underway to develop the long-range program plan (through FY-78) that will be "finalized" as soon as the "Program Letter" is received from SNS. The principal effort, at the present time, is on the design of the long-term compatiblity tests. The program plan should be ready for review by SNS by the latter part of August. 


\section{DISTRIBUTION}

No. of

$\underline{\text { Copies }}$

OFFSITE

AEC Chicago Patent Attorney

A. A. Churm

1

AEC Division of Applied Technology

E. E. Fowler

J. E. Machurek

R. W. Shivers

2

AEC Division of Biomedical and Environmental Research

J. N. Maddox

L. A. Miller

3

AEC Division of Production and Materials Management

F. P. Baranowski

R. K. Heusser

J. W. Pollock

12

AEC Division of Space Nuclear Systems

R. T. Carpenter

G. P. Dix

T. J. Dobry, Jr.

D. S. Gabriel

N. Goldenberg

H. Jaffe

W. K. Kern

A. P. Litman (3)

G. A. Newby

B. J. Rock

2

AEC Division of Waste Management and Transportation

F. K. Pittman

R. W. Ramsey, Jr.

1

AEC Oak Ridge Operations Office

D. C. Davis, Jr.

AEC Savannah River Operations Office

T. B. Hindman 
No. of

Copies

5

1

1

1

2

T. K. Keenan

R. N. Mulford

1

1

3

1

7

Mound Laboratory (AEC)

W. T. Cave

Naval Nuclear Power Division (Ft. Belvoir., VA)

F. E. Roselle

Naval Facilities Engineering Command

T. P. Fleming

G. E. Krauter

M. Starr

Navy Office of the Chief of Naval Operations (Wash., D.C.)

F. S. Adair

Oak Ridge National Laboratory (AEC)

R. S. Crouse

J. R. DiStefano

J. H. Gillette

E. Lamb

C. Ottinger

J. E. Ratledge

A F. Rupp

R. K. Huntoon 
No. of

Copies

1

1

1

ONSITE

3

AEC Richland Operations Office
P. G. Holsted
D. K. Jones
B. J. Melton

8

Atlantic Richfield Hanford Company
R. E. Isaacson
L. M. Knights
C. W. Malody
J. D. Moore
G. C. Oberg
H. P. Shaw
A. E. Smith
M. J. Szulinski

2

D. W. Douglas Laboratories

D. E. Knapp

W. E. Matheson

24

Battelle-Northwest

E. L. Alpen

J. W. Bartlett

R. E. Burns

T. D. Chikalla

G. J. Dau

R. L. Dillon

J. W. Finnigan

H. T. Fullam (3)

A. J. Haverfield

J. H. Jarrett

R. S. Kemper

R. P. Marshall

R. W. McKee 
J. M. Nielsen

R. E. Nightingale

L. D. Perrigo

A. M. Platt

C. A. Rohrmann

H. H. Van Tuyl

Technical Information Files (3) 